\title{
Nasal Septum Deviation and Inferior Nasal Concha Bone Hypertrophy in Class III Facial Deformity
}

\author{
Desviación del Septum Nasal e Hipertrofia de la Concha \\ Nasal Inferior en Deformidad Facial Clase III
}

\author{
Javier Villa ${ }^{1}$; Leonardo Brito ${ }^{2,3}$; Marcelo Parra ${ }^{2,4}$; Pablo Navarro ${ }^{3}$; Márcio de Moraes $^{6}$ \& Sergio Olate Oa $^{2,4}$
}

VILLA, J.; BRITO, L.; PARRA, M.; NACARRO, P.; DE MORAES, M.; OLATE, S. Nasal septum deviation and inferior nasal concha bone hypertrophy in Class III facial deformity. Int. J. Morphol., 38(6):1544-1548, 2020.

SUMMARY: The aim of this research was to analyze the morphology of the nasal septum and inferior nasal concha bone in class III facial deformities prior to orthodontic treatment in orthognathic surgery candidates. 40 subjects were included in this research. The inclusion criteria were an Angle class III, negative overjet and SNA angle less than $80^{\circ}$. Patients with facial asymmetry, facial trauma or who had undergone maxillofacial or ENT procedures were excluded. CBCT images were obtained for all the patients and the nasal septum deviation, morphology of inferior nasal concha bone and ostium of the maxillary sinus were analyzed and related to the complexity of the facial deformity expressed by the ANB angle and dental relations. The measurement was standardized by ICC and the data was analyzed using a chi square test and Spearman's coefficient with a p value $<0.005$ for statistical significance. Nasal septal deviation was observed in $77.5 \%$. The deviation angle was $13.28^{\circ}\left( \pm 4.68^{\circ}\right)$ and the distance from the midline to the most deviated septum was $5.56 \mathrm{~mm}$ $( \pm 1.8 \mathrm{~mm})$ with no statistical relation to the complexity of the facial deformity. The deviated nasal septum showed inferior nasal concha bone hypertrophy on the concave side of the nasal septum deviation $(\mathrm{p}=0.049)$. The open or closed condition of the maxillary sinus ostium was not related to any conditions in the septum or complexity of the facial deformity. Inferior nasal concha bone hypertrophy could be related to nasal septal deviation. The nasal condition in a class III facial deformity could not differ from the general population; careful in orthognathic surgery as to be assume in the Le Fort I Osteotomy and nasal approach related to nasal septum deviation and inferior nasal concha bone.

KEY WORDS: Facial deformity; Septum deviation; Orthognathic surgery; Rhinoplasty.

\section{INTRODUCTION}

The nasal septum is formed by the vomer bone and the perpendicular plate of ethmoid bone in the posterior segment and the quadrangular cartilage in the anterior segment. The cartilaginous nasal septum is the key to the midfacial growth center with significant influence on skeletal growth (Foster \& Holton, 2016).

From the embryological stage, the maxilla and the nasal structure have a close relationship (Ballanti et al., 2016), so that the nasal septum works as a growth plate in development and growth, affecting the entire environment.
As a result, changes in the nasal area and airway can lead to significant changes in craniofacial growth (Grauer et al., 2009).

In the case of nasal obstruction, nose breathing can change to mouth breathing, resulting in facial changes with an increase in lower facial height and transverse maxillary deficiency, increase of the mandibular plane and gonial angle, among others (El \& Palomo, 2011; Sevinc et al., 2013).

Nasal septum deviation is one of the most common

\footnotetext{
${ }^{1}$ Master in Dental Sciences Program, Dental School, Universidad de La Frontera, Temuco, Chile.

${ }^{2} \mathrm{PhD}$ Program in Morphological Sciences, Center of Excellence in Morphological and Surgical Studies, Medical School, Universidad de La Frontera Temuco, Chile.

${ }^{3}$ Universidad Autónoma de Chile, Temuco, Chile.

${ }^{4}$ Division of Oral, Facial and Maxillofacial Surgery, Dental School, Universidad de La Frontera, Temuco, Chile.

${ }^{5}$ Research Centre in Dental Sciences (CICO), Dental School, Universidad de La Frontera, Temuco, Chile.

${ }^{6}$ Division of Oral and Maxillofacial Surgery, Dental School, State University of Campinas, Sao Paulo, Brazil. Funding: DIUFRO DI20-0048
} 
variations in healthy adults over $80 \%$ (Prasad et al., 2013), and can occur at different stages of life and with varying degrees of deformity. The inferior nasal concha bone (inferior nasal turbinate) is responsible for controlling the atmospheric inflammatory and physiological agents that affect the mucosa and cause inflammation. In addition, in patients with septal deviation a compensatory hypertrophy of the inferior nasal concha bone can be found in the right and left sides (Berger et al., 2000).

Nasal septum deviation has no relation to age, sex or ethnicity (Serifoglu et al., 2017). However, the association between nasal septum deviation and facial asymmetries has been reported (Hafezi et al., 2010), This may lead to a hypothesis associated with the impact of nasal septum deformity and facial deformities. Previous studies have shown that subjects with a class III skeletal deformity have a higher airway volume than other subjects (Ravelo et al., 2020); however, information regarding the nasal apparatus is limited. The aim of this study was to identify septal deviations and changes in the inferior nasal concha bone in subjects with a class III facial deformity.

\section{MATERIAL AND METHOD}

A cross-sectional study was conducted on 40 subjects candidates for orthognathic surgery in Temuco, Chile. All subjects agreed to participate in the study on a voluntary basis; this study was approved by the research ethics committee of Universidad de La Frontera under protocol $027-17$.

Patients between 18 and 30 years of age of both sexes were included, who presented an indication for orthognathic surgery with an Angle class III malocclusion, negative overjet and SNA angle less than $80^{\circ}$. Patients with orthodontic treatment, patients classified as class III with only one or two inclusion criteria, subjects with facial asymmetry with deviated chin greater than $5 \mathrm{~mm}$ from the midline, subjects with a history of facial trauma or other type of facial intervention or previous ENT surgeries were excluded.

Cone beam computed tomography (CBCT) images of each patient were taken with a NewTom 3D Tomograph, Model VGi EVO (Verona, Italy), window 24 x $19 \mathrm{~cm}$, exposure time $110 \mathrm{kV}, 8 \mathrm{~mA}, 15 \mathrm{~s}$. The images were taken by two specialized technicians with 5 years of experience. The patient was positioned immobilized, upright, with the lips at rest and without forcing a muscle position. Once the image was obtained, the measurement was analyzed by a trained professional, using the NewTom NNT (Imola, Italy) software
In order to determine the sagittal plane, a line was drawn on the anterior nasal spine (ANS) and posterior nasal spine (PNS). Then, the coronal plane was drawn with the perpendicular to this line at the ANS point and another parallel line $10 \mathrm{~mm}$ posterior to the first line. In this position the facial midline was established using a line that began from the superior point of the ethmoid plate and ended at the ANS point.

\section{The following variables were analyzed:}

1) Nasal septum: The presence or absence of deviation was determined; the angle of deviation was analyzed with a line from the ridge of the crista galli to the septum at its lowest portion on the nasal floor and the line from the tangential crista galli point to the most lateral part of the deviation (Fig. 1). In addition, the distance between the midline of the nose and the most lateral part deviated from the nasal septum was measured (Fig. 2).

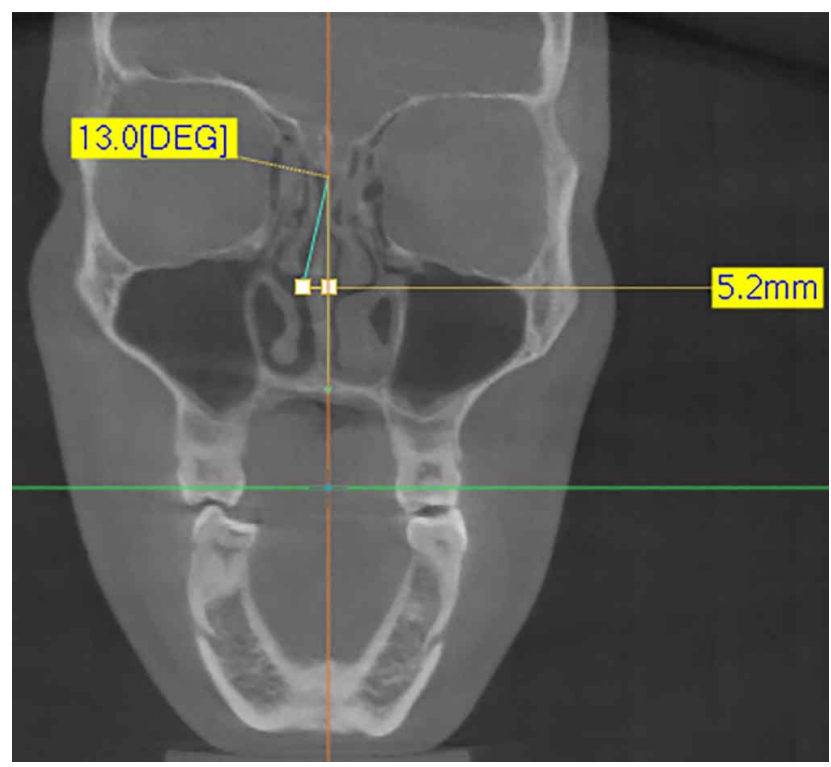

Fig. 1. CBCT showing measurement of the angle in the nasal septal deviation.

2) Inferior nasal concha bone (Inferior nasal turbinate): The area of the left and right inferior nasal concha bones was measured by obtaining the largest nasal septal deviation in the coronal section (Fig. 3).

3) Maxillary sinus ostium: The CBCT identified whether the maxillary sinus ostium was open (permeable) or obliterated (closed) with epithelial tissue (Fig. 4).

In addition, ANB angle and sagittal overjet measurement were taken for subjects. All measurements were taken by two observers (JV and LB), establishing an 
intraclass relationship in a pilot study of 10 subjects with an ICC of 0.84, considered appropriate for the study. For the statistical analysis the IBM SPPS Statistics software for Windows was used (Version 22, IBM Corp.). Additionally, the chi square and Spearman's Rho correlation coefficient tests were used to evaluate the relationship betweenvariables, considering $\mathrm{p}$ value $<0.05$ to establish significant differences.

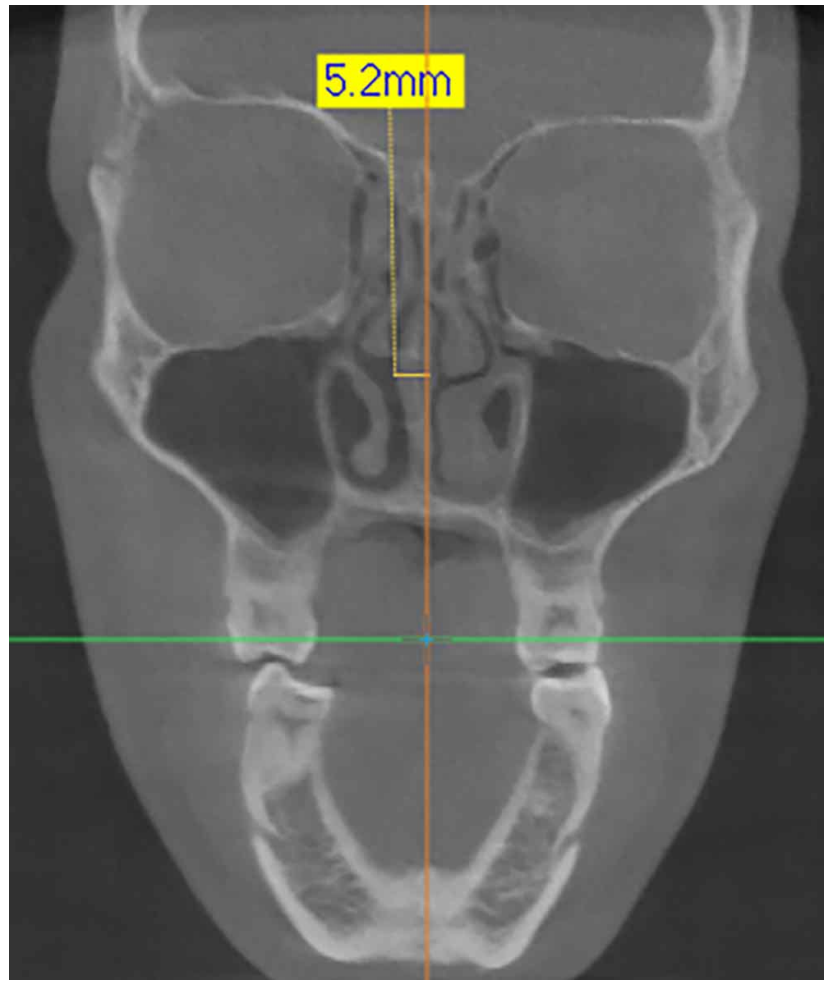

Fig. 2. Measurement (mm) obtaining in the CBCT in the most lateral view of the septum deviation.

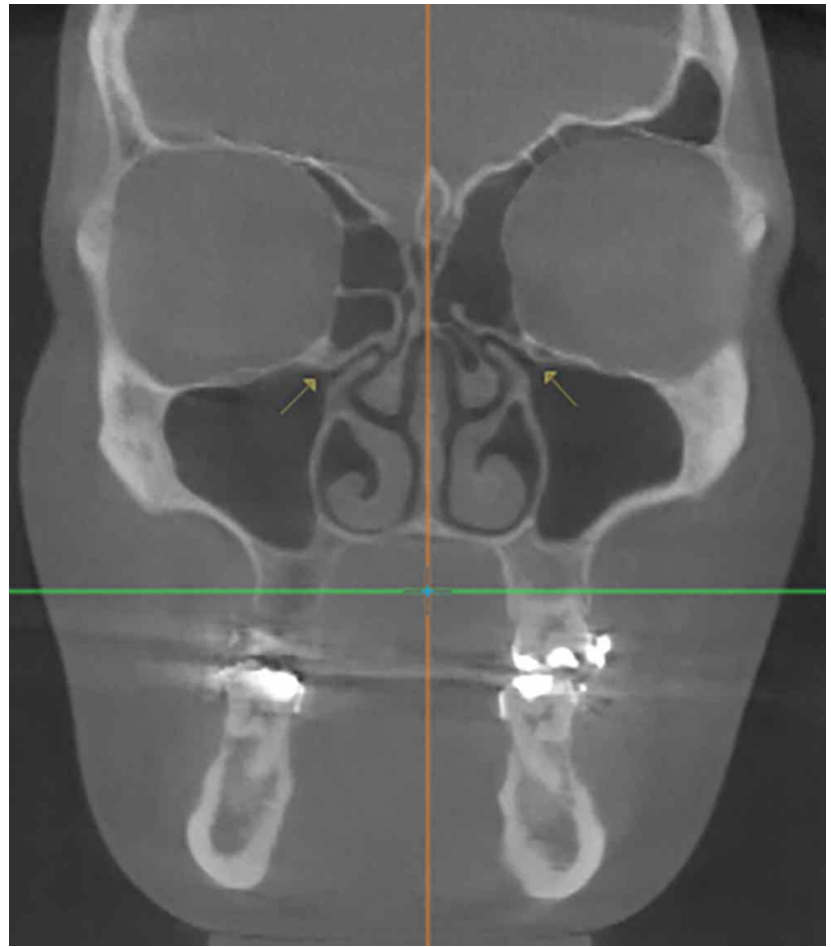

Fig. 4. Definition of the ostium position in CBCT and its assessment as closed or open.

\section{RESULTS}

The 40 subjects were studied, 20 men and 20 women, with an average age of 21.25 years. The negative overjet of the subjects was -8.8 to $0(-1.53 \pm 2.1)$ and the ANB angle was -9.2 to $0.3(-1.97 \pm 2.12)$.

The nasal septum was deviated in 31 cases $(77.5 \%)$.

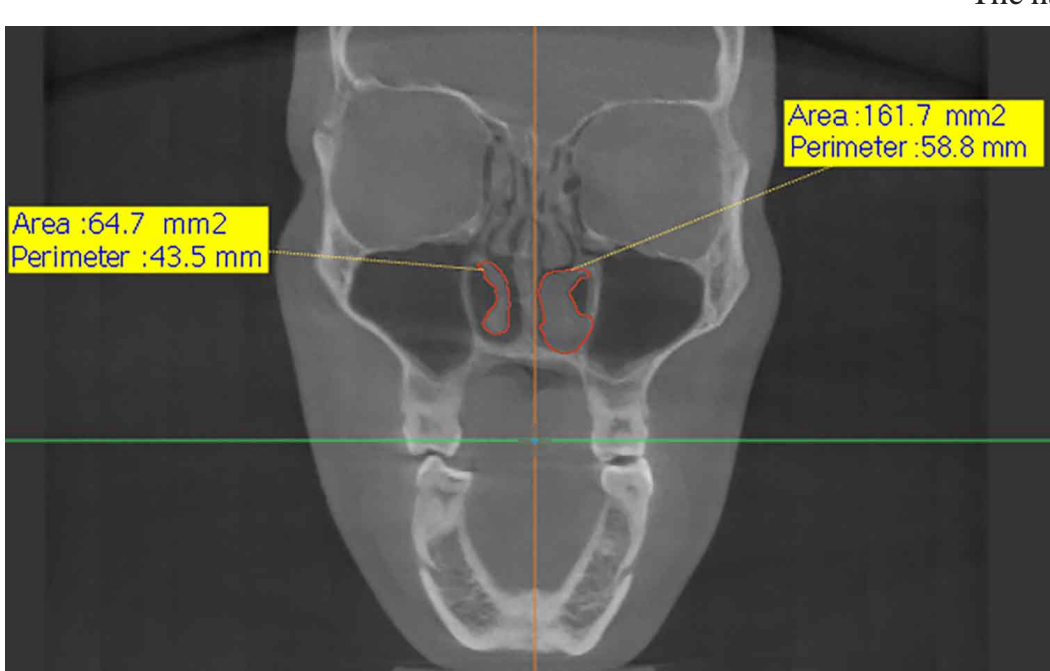

Fig. 3. CBCT showing the measurement of the left and right inferior turbinate, comparing the area between them.
This was observed in only one direction in all the subjects with nasal septal deviation, with $58 \%$ to the right and $42 \%$ to the left with no significant differences between them $(\mathrm{p}=0.399)$. The deviation angle was $13.28^{\circ}\left( \pm 4.68^{\circ}\right)$, with no significant differences in relation to the severity of the facial deformity determined by the ANB angle ( $\mathrm{p}=0.197$ ) or by the degree of negative overjet $(\mathrm{p}=0.215)$. Depending to the deviation of the nasal septum one side was determined to be concave and the other side convex. The deviation to the convex side was extended on average by $5.56 \mathrm{~mm}( \pm 1.8$ $\mathrm{mm})$, measured from the facial midline, without significant differences according to the severity of the facial deformity $(\mathrm{p}=0.137)$. 
The hypertrophic turbinate appeared more frequently on the concave side of the septal deviation, with an area of $146.77 \mathrm{~mm}^{2}$ on the concave side and $130.38 \mathrm{~mm}^{2}$ on the convex side, which was significantly related to the direction of deviation $(\mathrm{p}=0.049)$.

In the 31 subjects with septal deviation, $27.6 \%$ had closed ostia on both sides and $34.4 \%$ had open ostia on both sides, while $38.1 \%$ only had closed ostium on one side with no significant differences between groups $(\mathrm{p}=0.194)$. Of subjects with a straight nasal septum $(22.5 \%), 33 \%$ had both ostias closed. Considering 62 maxillary ostias in with the 31 patients with septal deviation, ostiums were observed to be covered by epithelial tissue in $46.5 \%$ of the cases, while there was visibility of the permeable passage of the ostium in $53.5 \%$, without presenting significant differences $(\mathrm{p}=0.51)$. There was no significant relationship between the condition of the ostium and the direction of the deviation.

\section{DISCUSSION}

From the embryological stage, the maxilla and the nasal structure have a close relationship (Ballanti et al.), so that the nasal septum works as a growth plate in development and growth, affecting the entire environment.

Some studies have suggested that nasal deviation is correlated with differences in the growth of facial middle third (Mladina et al., 2008) and a substancial delay in growth on the concave side of the deviated nose (Hafezi et al.); this was confirmed by the observation of a thicker and smaller nasal bone on the concave side (Serifoglu et al.); hence, nasal function and obstruction are correlated with some aspects of the facial profile (Huynh et al., 2011). The present study, is based on these arguments; although class III subjects have been identified as presenting higher airway volumes (Ravelo et al.), the sagittal deficiency of maxillary growth suggests the hypothesis of a higher number of nasal alterations. However, this hypothesis cannot be fully confirmed by the results of this study.

There is evidence in humans that nasal septal deviations are associated with a reduction in facial dimensions, and the association between the deviation and facial asymmetries has been established (Hafezi et al.). This study reports an analysis of 40 subjects with a class III deformity, where $77.5 \%$ of the cases presented nasal septal deviation. In the general population not segmented by facial conditions, it has been identified that as a general rule $80 \%$ of subjects could have nasal septal deviation (Prasad et al.) and that it could begin at different stages of life and at different degrees of deformity. Therefore, the results of the present research in terms of septal deviation are not different from those previously observed for the general population.

The origin of facial deformities responds to environmental and genetic factors, so that the time when the deviation of the septum occurs can affect the form of maxillary growth (Goulart et al., 2018); therefore, septal deviation can be produced at different stages of life and is not necessarily related to the skeletal growth model of the subject. In this regard, the average septal deviation in the non-segmented population was $13.5^{\circ}\left( \pm 5^{\circ}\right)$ and the average volume deviation was $4.76 \pm 0.8 \mathrm{~cm} 3$ (Orham et al., 2014). The results of this research report a septal deviation of $13.28^{\circ}$ $\left( \pm 4.68^{\circ}\right)$ and a distance of $5.56 \mathrm{~mm}( \pm 1.8 \mathrm{~mm})$ at the highest point of deviation, indicating similarity with the general population. Nasal obstruction may be another factor involved in the development of morphological alterations. The NOSE scale is used to assess quality of life in nasal obstruction, but it has not been shown between different skeletal classes (Rodrigues et al., 2017).

However, inferior nasal concha bone hypertrophy (ITH) is at least the cause of the $20 \%$ nasal obstruction (Seeger et al., 2003). ITH occurs on the concave side of the deviated septum (Berger et al.) and the absence of surgical management may cause failures of septoplasties in more than $30 \%$ of the cases (Uzun et al., 2004). The findings in this study only identified increases in the inferior nasal concha bone on the concave side of the septum when they appeared, showing significant differences between the right and left sides $(\mathrm{p}=0.049)$. This aspect is also consistent with other studies on non-segmented population that reported higher hypertrophic turbinates, including medial mucosa, bone and lateral mucosa (Orhan et al., 2014) associated with the concave side of the deviated septum. Demirci et al. (2016) studied 199 CBCT, identifying a statistically greater volume of the inferior nasal concha bone on the concave side of the deviation, which confirms our findings in class III facial deformities. ITH on the concave side of the septal deviation can be reactive and compensatory for the area in the nostril, so that this hypertrophy can be caused by a septal deviation, which is an important cause of the nose to mouth change of breathing. In orthognathic surgery, these considerations are very important in the integrative facial surgical management, considering the solution of respiratory problems.

Turbinate hypertrophy involves an increase in the size of the mucosa, which may cause drainage disorders that affect ciliary function, leading to secondary obstruction and infection (Gencer et al., 2013). In fact, nasolacrimal duct obstruction are observed on the concave side of the nasal septum (Taban et al., 2011). Lee et al. (2013) reported that 
the higher degree of facial asymmetry and nasal septal deviation was associated with increased nasolacrimal duct obstruction (Lee et al.). However, our findings did not indicate significant differences, given that $27.6 \%$ had closed ostia on both sides and $34.4 \%$ had open ostia on both sides, while only $38.1 \%$ presented closed ostium on one side with no significant differences between the groups $(\mathrm{p}=0.194)$ on the concave or convex side. It is likely that the age of the subjects included may have an effect on the adaptability of the epithelium and the drainage of the maxillary sinus.

Finally, the authors conclude that there is an ITH on the concave side of the nasal septal deviation in facial class III deformity and that no correlation between the nasal septum deviation and the complexity of the facial deformity can be established. The present data suggest the importance of the nasal condition in the plan for orthognathic surgery and the execution of the surgical procedure.

VILLA, J.; BRITO, L.; PARRA, M.; NAVARRO, P.; DE MORAES, M.; OLATE, S. Desviación del septum nasal e hipertrofia de la concha nasal inferior en deformidad facial Clase III. Int. J. Morphol., 38(6):1544-1548, 2020

RESUMEN: El objetivo de esta investigación fue analizar la morfología del septum y la concha nasal inferior en sujetos con deformidad facial clase III previo al tratamiento de ortodoncia preparatorio para cirugía ortognática. Fueron incluidos 40 sujetos en esta investigación. Los criterios de inclusión fueron la de presentar una clase III de Angle, overjet negativo y ángulo SNA menor que $80^{\circ}$. Sujetos con asimetría facial, trauma facial o quienes presentaron algún tipo de procedimiento maxilofacial o de otorrinolaringología fueron excluidos. Tomografía computadorizada cone beam (CBCT) fueron obtenidas para todos los sujetos donde le morfología del septum nasal, morfología de la concha nasal inferior y el ostium del seno maxilar fueron analizados y relacionados con la complejidad de la deformidad facial expresada como ángulo ANB y relaciones dentales. Las medidas fueron estandarizadas por el ICC y los datos fueron analizados utilizando la prueba chi cuadrado y coeficiente de Spearman con un valor de $\mathrm{p}<0,05$ para obtener relaciones significativas. La desviación del septum nasal se observó en el 77,5 \%; el ángulo de desvío fue de $13,28^{\circ}\left( \pm 4,68^{\circ}\right)$ y la distancia de desvío del septum desde la línea media fue de $5,56 \mathrm{~mm}( \pm 1,8 \mathrm{~mm})$ sin diferencias estadísticas en relación a la complejidad de la deformidad. El desvío de septum nasal demostró hipertrofia de la concha nsal inferior en el lado cóncavo del septum desviado ( $\mathrm{p}=0,049)$. La condición de ostium abierto o cerrado no fue relacionado con ninguna condición del septum nasal o complejidad de la deformidad facial. La hipertrofia de la concha nasal inferior se relacionó con el desvío de septum nasal. La condición nasal en deformidad facial de clase III no es diferente de la observada en la población general; cuidados deben ser realizados en cirugía ortognática para el desarrollo de la osteotomía de Le Fort I y aproximación nasal en relación al desvío de septum y probable alteración de la concha nasal inferior.

PALABRAS CLAVE: Deformidad facial; Desvío de septum; Cirugía ortognática; Rinoplastía.

\section{REFERENCES}

Ballanti, F.; Baldini, A.; Ranieri, S.; Nota, A. \& Cozza, P. Is there a correlation between nasal septum deviation and maxillary transversal deficiency? A retrospective study on prepubertal subjects. Int. J. Pediatr. Otorhinolaryngol., 83:109-12, 2016.

Berger, G.; Hammel, I.; Berger, R.; Avraham, S. \& Ophir, D. Histopathology of the inferior turbinate with compensatory hypertrophy in patients with deviated nasal septum. Laryngoscope, 110(12):2100-5, 2000.

Demirci, S.; Ertan, N.; Tuzuner, A. \& Ozcan, M. K. Correlation between the septal body and the nasal turbinates in patients with deviated nasal septum. J. Craniofac. Surg., 27(1):166-9, 2016

El, H. \& Palomo, J. M. Airway volume for different dentofacial skeletal patterns. Am. J. Orthod. Dentofacial Orthop., 139(6):e511-21, 2011.

Foster, A. \& Holton, N. Variation in the developmental and morphological interaction between the nasal septum and facial skeleton. Anat. Rec. (Hoboken), 299(6):73040, 2016.

Gencer, Z. K.; Ozkırıs, M.; Okur, A.; Karaçavus, S. \& Saydam, L. The effect of nasal septal deviation on maxillary sinus volumes and development of maxillary sinusitis. Eur. Arch. Otorhinolaryngol., 270(12):3069-73, 2013.

Goulart, D. R.; Sigua-Rodriguez, E. A.; Fariña, R. \& Olate, S. Condylar hyperplasia in a monozygotic twin girl: an argument about etiology. J. Craniofac. Surg., 29(3):599$602,2018$.

Grauer, D.; Cevidanes, L. S. H.; Styner, M. A.; Ackerman, J. L. \& Proffit, W. R. Pharyngeal airway volume and shape from cone-beam computed tomography: relationship to facial morphology. Am. J. Orthod. Dentofacial Orthop., 136(6):805-14, 2009.

Hafezi, F.; Naghibzadeh, B.; Nouhi, A. \& Yavari, P. Asymmetric facial growth and deviated nose: a new concept. Ann. Plast. Surg., 64(1):47-51, 2010.

Huynh, N. T.; Morton, P. D.; Rompré, P. H.; Papadakis, A. \& Remise, C. Associations between sleep-disordered breathing symptoms and facial and dental morphometry, assessed with screening examinations. Am. J. Orthod. Dentofacial Orthop., 140(6):762-70, 2011

Lee, J. S.; Lee, H.; Kim, J. W.; Chang, M.; Park, M. \& Baek, S. Association of facial asymmetry and nasal septal deviation in acquired nasolacrimal duct obstruction in East Asians. J. Craniofac. Surg., 24(5):1544-8, 2013.

Mladina, R.; Cujic', E.; Subaric', M. \& Vukovic', K. Nasal septal deformities in ear nose, and throat patients: an international study. Am. J. Otolaryngol., 29(2):75-82, 2008 .

Orhan, I.; Aydın, S.; Ormeci, T. \& Yılmaz, F. A radiological analysis of inferior turbinate in patients with deviated nasal septum by using computed tomography. Am. J. Rhinol. Allergy, 28(1):e68-72, 2014.

Prasad, S.; Varshney, S.; Bist, S.S.; Mishra, S. \& Kabdwal, N. Correlation study between nasal septal deviation and rhinosinusitis. Indian J. Otolaryngol. Head Neck Surg., 65(4):363-6, 2013

Ravelo, V.; Olate, G.; Moya, M. P.; Brito, L.; Garay, I. \& Olate, S. 3-D airway analysis related to facial morphology. Int. J. Morphol., 38(2):423-6, 2020.

Rodrigues, M. M.; Passeri, L. A.; Monnazzi, M. S.; Gabrielli, M. F. R.; Gabrielli, M. A. C. \& Pereira-Filho, V. A. Evaluation of nasal obstruction in various sagittal skeletal deformity of jaws. J. Craniofac. Surg., 28(8):e790-2, 2017.

Seeger, J.;Zenev, E.; Gundlach, P.; Stein, T. \& Müller, G. Bipolar radiofrequency-induced thermotherapy of turbinate hypertrophy: pilot study and 20 months' follow-up. Laryngoscope, 113(1):130-5, 2003.

Serifoglu, I.; Oz, I’. I’ '; Damar, M.; Buyukuysal, M. C.; Tosun, A. \& Tokgöz, Ö. Relationship between the degree and direction of nasal septum deviation and nasal bone morphology. Head Face Med., 13:3, 2017.

Sevinc, O.; Barut, C.; Kacar, D. \& Is, M. Evaluation of the lateral wall of the nasal cavity in relation to septal deviation. Int. J. Morphol., 31(2):438-43, 2013.

Taban, M.; Jarullazada, I.; Mancini, R.; Hwang, C. \& Goldberg, R. A. Facial asymmetry and nasal septal deviation in acquired nasolacrimal duct obstruction. Orbit, 30(5):226-9, 2011.

Uzun, L.; Savranlar, A.; Beder, L. B.; Ugur, M. B.; Cinar, F.; Ozdemir, H. \& Gundogdu, $\mathrm{S}$. Enlargement of the bone component in different parts of compensatorily hypertrophied inferior turbinate. Am. J. Rhinol., 18(6):405-10, 2004.

Corresponding author:

Prof. Sergio Olate, DDS, PhD

Division of Oral and Maxillofacial Surgery

Universidad de La Frontera

Temuco- CHILE

Email: sergio.olate@ufrontera.cl

Received: 16-06-2020

Accepted: 27-07-2020 